\title{
Noen tiltak kan redusere infeksjoner ved sentralt venekateter
}

Utvalg og oversettelse ved Liv MereteReinar

Illustrasjonsfoto: Colourbox .com

\section{Hva er effekten av forskjel- lige tiltak som skal redusere kateterrelaterte blodstrøms- infeksjoner (CRBSI's) og kolonisering på intensivavde- linger (ICU)?}

\section{SYSTEMATISK OVERSIKT}

Studiene som ble selektert evaluerte korttids $(<21$ dager $)$ «nontunnelled»- kateter og rapporterte insidensen av CRBSI hos pasienter $\geq 18$ år innlagt $\mathrm{i}$ intensivavdeling. Eksklusjonskriteriene var studier som evaluerte helt implanterte, perifere sentrale venekateter eller hemodialyse-kateter, «arterial venous catheters» og de som ble gitt i diverse andre settinger. Utfallsmål var CRBSI og kolonisering.

\section{METODE}

Medline, CINAHL, EMBASE/ experta Medica, Current Contents, Cochrane Library, Health Services Technology, Centre for Disease Control guideline and reports, og åtte andre databaser ble søkt (fra 1985 til februar 2007) for observasjonsstudier eller randomiserte, kontrollerte studier (RCTer) publisert på engelsk. 14 RCTer $(n=2235$, mean gjennomsnittlig alder 59 år, basert på 10 RCTer), én ikkeRCT og åtte observasjonsstudier møtte seleksjonskriteriene. Sju RCTer rapporterte randomiseringsmetode, én rapporterte skjult allokering og fire hadde blinding av utfallsmål.

\section{HOVEDRESULTATER}

Enkelte RCTer viste at desinfiserbare nålfrie overganger reduserte risikoen for CRBSI sammenliknet med treveisoverganger (tabell): desinfeksjon av hud med klorhexidin glukonat 2 prosent eller povdone iodine (PI) 5 prosent pluss etanol 70 prosent var mer effektivt enn PI 10 prosent alene. Og bruk av Vitacuff var mer effektivt enn ingen «cuff» for å redusere kolonisering. Femoralt innstikk var mer utsatt for kolonisering enn subklavia-innstikk (tabell).

\section{KONKLUSJON}

Noen tiltak reduserer risikoen for kateterrelatert blodstrømsinfeksjoner og kolonisering på intensivavdeling.

Sammendrag fra: Ramritu P, Halton $\mathrm{K}$, Cook D et al. Catheter-related bloodstream infections in intensive care units: a systematic review with meta-analysis. J Adv Nurs 2008;62:321.

Korrespondanse: Dr N Graves, Queensland University of Technology, Brisbane, Queensland, Australia; n.graves@qut.edu.au

Finansiering: National Health and Medical Research Council of Australia «Clinical impact rating»: critical care 6/7; infectious disease 6/7
Denne systematiske oversikten fra Ramus og medarbeidere gir godt grunnlag for å kunne redusere den risikoen for infeksjon som er assosiert med innleggelse og ivaretakelse av sentrale venekateter. Oversikten støtter bruk av andre strategier enn den økte bruk av dyre antimikrobiske katetre. Den viser at enkle, spesifikke tiltak, i tillegg til mer generelle strategier som opplæring av personell, infeksjonskontroll og feedback, er effektive.

Den eksplisitte hensikten med oversikten var å sammenlikne tiltak, andre enn antimikrobiske katetre, for å redusere CRBSI. Forfatterne tar for gitt at antimikrobiske katetre er dyrere enn andre tiltak, selv om kostnadene ved tiltakene ikke ble tatt med. Kostnadene er derfor uklare. Forfatterne konkluderer med at «tiltak utenom antimikrobiske kateter kan være brukbare for å redusere risiko». Det som er uklart er i hvilken grad antimikrobiske kateter i tillegg til andre tiltak bedrer utfall for pasientene. Dette var ikke fokus for oversikten og begrenser der- 
TABELL: Sammenlikning av flere tiltak for å redusere kateterrelaterte blodstrømsinfeksjoner på intensivavdeling*

\begin{tabular}{|c|c|c|c|c|c|}
\hline Utfall ved 7 uker & Antall studier (n) & Sammenlikning & Hendelsesrate & $\operatorname{RRR}(95 \% \mathrm{KI})$ & NNT (KI) \\
\hline CRBSI & $1(278)$ & $\begin{array}{r}\text { «disinfectable } \\
\text { needle-free } v \text { stopcock } \\
\text { connector» }\end{array}$ & $0,7 \%$ versus $5 \%$ & $86 \%$ (17 til 98) & $\begin{array}{r}24(21 \text { til } \\
115)\end{array}$ \\
\hline \multirow[t]{5}{*}{ Kolonisering } & $1(144)$ & $\mathrm{CHL}, 2 \%$ versus $\mathrm{PI} 10 \%$ & $6 \%$ versus $19 \%$ & $69 \%$ (12 til 83) & $8(7$ til 43$)$ \\
\hline & $1(223)$ & $\begin{array}{r}\text { PI } 5 \% \text { + ethanol } 70 \% \\
\text { versus PI } 10 \%\end{array}$ & $13 \%$ versus $35 \%$ & $62 \%$ (35 til 78) & 5 (4 til 9) \\
\hline & $1(55)$ & $\begin{array}{r}\text { Vitacuff }+ \text { PNB versus } \\
\text { PNB alene }\end{array}$ & $7,7 \%$ versus $34 \%$ & $78 \%$ (8 til 95) & $4(4$ til 37) \\
\hline & & & 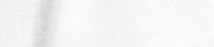 & RRI (KI) & NNH (KI) \\
\hline & $1(270)$ & $\begin{array}{r}\text { Femoral versus } \\
\text { subklavia inj. }\end{array}$ & $14 \%$ versus $2,2 \%$ & $\begin{array}{r}540 \%(90 \text { til } \\
2020)\end{array}$ & $9(3$ til 51) \\
\hline
\end{tabular}

${ }^{*} \mathrm{CHL}$, klorhexidin; PI, povidone iodine; PNB, polymyxin, neomycin og bacitracin. RRR, RRI,NNT,NNH og KI er kalkulert fra kontrollgruppens hendelsesrate og relativ risiko i artikkelen ved bruk av "random effect model".

ved anvendelsen av resultatene i klinisk praksis.

Funnene fra oversikten har klare implikasjoner for sykepleiere som arbeider på intensivavdelinger. Spesifikke tiltak inkluderer hvor kateteret injiseres, hvilken type huddesinfeksjon som brukes, bytte av kateter på nytt injeksjonssted eller bruk av samme injeksjonssted, overgan- ger og «hub»-typer, «attachabel cuffs», antall kateterlumen og opplæringsstrategier. Noen intensivsykepleiere vil påstå at funnene er vel kjente og iverksatt. Men denne oversikten gir en samlet vurdering, i stedet for mange informasjonskilder, og bringer tiltak og strategier fra ideer og teorier fram til en systematisk tilnærming for praksis.
Likevel, flere spørsmål reiser seg om hva som er den beste tilnærmingen.

Sammenlikning av flere tiltak for å redusere kateterrelaterte blodstrømsinfeksjoner på intensivavdeling*

Stephen D Krau, PhD, RN, CNE, CT. Vanderbit University School of nursing, Nashville, Tennesee, USA. 